\title{
The tetrapod fauna of the upper Permian Naobaogou Formation of China: 1. Shiguaignathus wangi gen. et sp. nov., the first akidnognathid therocephalian from China
}

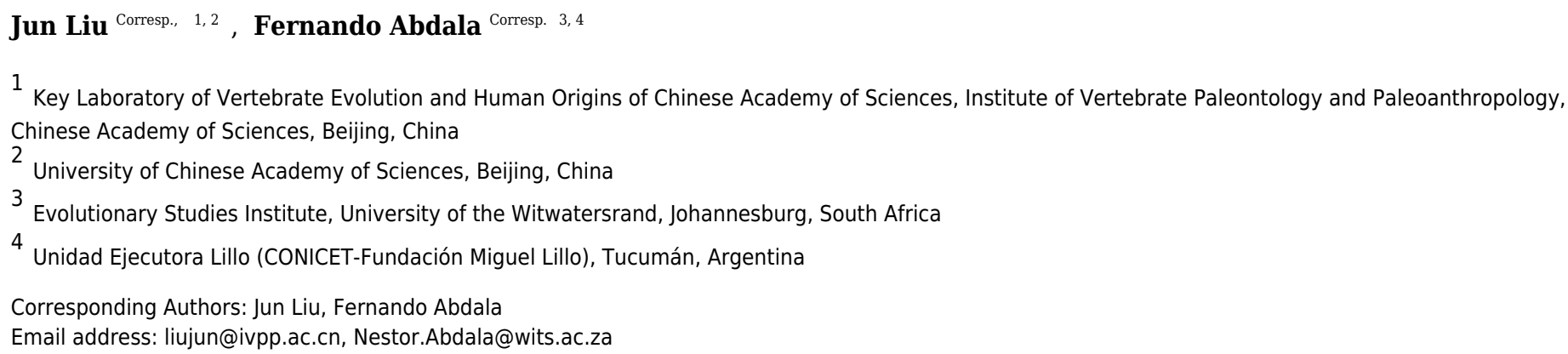

The Permian from China has a well-known terrestrial record where approximately 30 tetrapod taxa, including several therapsids, have been described. However, the record of therocephalians in China has remained elusive. Shiguaignathus wangi gen. et sp. nov., discovered in the Member III of the Naobaogou Formation, Nei Mongol, China, is here described. This is the first therocephalian recovered from this fauna and only the second from the Permian of China. It is represented by a well-preserved robust snout of a mediumsized animal. This is the first akidnognathid reported from the Chinese Permian and only the second genus from Laurasia as one genus is known from Russia whereas the remaining members of the group are from the South African Karoo Basin. A phylogenetic analysis of therocephalians supports a basal position of $S$. wangi within Akidnognathidae, followed by the Russian Annatherapsidus. Akidnognathidae is the latest major group of therocephalian appearing in the fossil record, and one of the few that does not have species from South Africa representing its most basal members. 
1 The tetrapod fauna of the Upper Permian Naobaogou Formation of China: 1. Shiguaignathus

2

3

$4{ }^{1}$ Key Laboratory of Vertebrate Evolution and Human Origins of Chinese Academy of Sciences,

5 Institute of Vertebrate Paleontology and Paleoanthropology, Chinese Academy of Sciences,

6 Beijing, China

$7 \quad{ }^{2}$ University of Chinese Academy of Sciences, Beijing, China

$8{ }^{3}$ Evolutionary Studies Institute, University of the Witwatersrand, Johannesburg, South Africa

$9{ }^{4}$ Unidad Ejecutora Lillo (CONICET-Fundación Miguel Lillo), Tucumán, Argentina

\section{ABSTRACT}

The Permian from China has a well-known terrestrial record where approximately 30 tetrapod taxa, including several therapsids, have been described. However, the record of therocephalians in China has remained elusive. Shiguaignathus wangi gen. et sp. nov., discovered in the Member III of the Naobaogou Formation, Nei Mongol, China, is here described. This is the first therocephalian recovered from this fauna and only the second from the Permian of China. It is represented by a well-preserved robust snout of a medium-sized animal. This is the first akidnognathid reported from the Chinese Permian and only the second genus from Laurasia as one genus is known from Russia whereas the remaining members of the group are from the South African Karoo Basin. A phylogenetic analysis of therocephalians supports a basal position of $S$. wangi within Akidnognathidae, followed by the Russian Annatherapsidus. Akidnognathidae is the latest major group of therocephalian appearing in the fossil record, and one of the few that 
does not have species from South Africa representing its most basal members.

\section{INTRODUCTION}

Therocephalians were important components of middle to late Permian terrestrial faunas in Russia and Africa (Abdala et al. 2014; Huttenlocker et al. 2015; Ivakhnenko 2011). They represent a rather diverse lineage, especially in the late Permian, with some members, e.g., Glanosuchus in the middle Permian and Theriognathus at the end of the Permian, also being abundant. Two lineages are typical of the middle Permian, namely lycosuchids and scylacosaurids, and they are represented by less than ten species. Three large therocephalian lineages are recognized in the late Permian, Akidnognathidae, Whaitsoidea and Baurioidea, the first two being principally late Permian, while the latter is also well represented in the Triassic (Huttenlocker 2014).

In China, late Permian tetrapods have been collected from Wutonggou and Guodikeng formations of Xinjiang, the Naobaogou Formation of Nei Mongol, the Shangshihezi Formation of Henan, and the Sunjiagou Formation of Shanxi (Li et al. 2008). Therocephalians, however, are almost unknown in the Chinese terrestrial Permian. The baurioid therocephalian Urumchia lii was initially reported as late Permian in age (Young 1952), but subsequently has been demonstrated to be from the Lower Triassic Jiucaiyuan Formation (Sun 1991). Recently, Liu and Abdala (2017) reported a therocephalian from the Guodikeng Formation at the Dalongkou section of Xinjiang that is most likely latest Permian in age. Other Chinese therocephalians were collected from Triassic layers and are member of the baurioids. 
43 within the Daqing Mountains. It conformably overlies the dark purple clastic Shiyewan

44 Formation, and underlies coarse sandstones of the Laowopu Formation. The Naobaogou

45 Formation includes three sedimentary cycles, corresponding to three lithological members (I, II

46 and III), which begin with a thick conglomerate layer and are dominated by purple siltstone.

47 Tetrapod fossils from this Formation were first discovered in 1982 by the team of Yeh H-K, Gao

48 Ke-Qin and Zhu Yang-Long from the Institute of Vertebrate Paleontology and Paleoanthropology

49 of the Chinese Academy of Sciences. This formation produced the dicynodont Daqingshanodon

50 limbus (Zhu 1989), the captorhinid Gansurhinus qingtoushanensis (Li \& Cheng 1997; Reisz et al.

51 2011), and tetrapod burrows (Liu \& Li 2013) (Fig. 1). In three field seasons (2009-2011), a team

52 lead by the senior author discovered fossils in the Naobaogou Formation of the Daqingshan area

53 in Nei Mongol. More than 20 dicynodont specimens, five therocephalians and two parareptiles

54 were collected. Most of the specimens come from the middle portion of the Naobaogou

55 Formation, but this probably reflects an uneven collecting strategy, as the vertebrate fossils are

56 known to be distributed throughout the Naobaogou Formation. Considering the fossils recovered,

57 a late Permian age is attributed here to this formation,. Therocephalian discoveries confirm the

58 finding of Zhu (1989) who reported members of this group in the Naobaogou Formation, though

59 these fossils are lost and were never described.

60 In this paper we describe the first therocephalian from the Naobaogou Formation,

61 represented by a well-preserved snout of a medium-sized animal. This discovery documents the

62 first representative of an akidnognathid therocephalian from China. Members of this group are

63 profusely represented in South Africa and known by a basal representative, Annatherapsidus,

64 from the Russian late Permian (Huttenlocker et al. 2015). This Russian genus is known from two 
65 species, abundantly represented by $A$. petri and the rare $A$. postum known only by an isolated

66 lower jaw (Ivakhnenko 2011). In addition, a specimen of this group was recently identified in the

67 Lower Triassic of Antarctica (Huttenlocker and Sidor 2012). Besides being the second Chinese

68 Permian therocephalian, this discovery represents only the second akidnognathid genus known

69 from Laurasia.

70 Nomenclatural acts - The electronic version of this article in Portable Document Format (PDF)

71 will represent a published work according to the International Commission on Zoological

72 Nomenclature (ICZN), and hence the new names contained in the electronic version are

73 effectively published under that Code from the electronic edition alone. This published work and

74 the nomenclatural acts it contains have been registered in ZooBank, the online registration system

75 for the ICZN. A ZooBank LSID (Life Science Identifier) can be resolved and the associated

76 information viewed through any standard web browser by appending the LSID to the prefix

77 http://zoobank.org/. The LSID for this publication is: urn:1sid:zoobank.org:pub: 960FC15A-

78 B1D5-402A-BB16-2FE79A5F0321. The online version of this work is archived and available

79 from the following digital repositories: PeerJ, PubMed Central and CLOCKSS.

80
SYSTEMATIC PALEONTOLOGY

THERAPSIDA Broom, 1905

THEROCEPHALIA Broom, 1903

EUTHEROCEPHALIA Hopson and Barghusen, 1986

AKIDNOGNATHIDAE Nopcsa, 1928

SHIGUAIGNATHUS WANGI gen. et. sp. nov. 
86 Etymology — 'Shiguai' refers to the district in which the fossil was collected, 'gnathus' is the

87 Greek word for jaw; 'Wang' is after Wang Yu, the technician who discovered the specimen.

88 Holotype - IVPP V 23297, a partial snout lacking its roof.

89 Type Locality and Horizon —Locality DQS 28, Naobaogou, Shiguai, Baotou, Nei Mongolia,

90 China; lower part of Member III, Naobaogou Formation (Fig. 1).

91 Diagnosis - A medium sized therocephalian showing the following combination of characters: as

92 typical of akidnognathids, present a robust snout, a wide anterior portion of the vomer contacting

93 the premaxilla and five upper incisors. As in Annatherapsidus petri, two processes of the anterior

94 margin of the palatine extend far anterior to the maxilla-palatine foramen. As in some specimens

95 of Promoschorhynchus and of Olivierosuchus, there is only one precanine. Autapomorphies of

96 the new species are the nearly straight and parasagittal crista choanalis directed towards the

97 middle of the suborbital vacuity and ending anterior to the vacuity, the presence of eight

98 postcanines (the largest number reported for an akidnognathid), posterior margin of the choana

99 extending to the level of the third postcanine, and small suborbital vacuity in relation to others

100 akidnognathids.

101 DESCRIPTION

102 The specimen is represented by the snout, partially preserved dorsally, but with a pristine

103 palate (Figs. 2, 3). Taphonomically it is tilted slightly to the left.

104 The premaxilla forms the anterior end of the snout which projects anteriorly to the level of

105 the first incisors. The midline premaxillary suture is visible in anterior view, but not on the palate.

106 The posterior margin of the premaxilla is in contact with the maxilla and covered dorsolaterally 
107 by the septomaxilla (Fig. 2). The suture between the premaxilla and maxilla extends

108 anterodorsally in front to the canine alveolus. The premaxilla forms a ventral plate that

109 encompasses the alveoli of the five upper incisors (Fig. 3). In lateral view, the alveolar margin is

110 nearly horizontal. On the palate, the premaxilla meets the vomer with a short triangular

111 posteriorly-directed vomerine process (Fig. 3B). The premaxillary foramen lies posterior to the

112 alveolus of the first incisor, near the medial suture between the premaxillae, but it can only be

113 observed on the dorsal surface of the bone (Fig. 3A).

114 A portion of the left dorsal process of the septomaxilla is preserved, whereas the large right

115 septomaxilla is nearly complete with a convex lateral surface well exposed outside of the external

naris (Fig. 2B). A small septomaxillary foramen is bordered anteriorly by the septomaxilla and posteriorly by the maxilla.

On the left side, anterior to the canine, the maxilla overlaps the lateral side of the premaxilla at the level of the last incisor. The facial plate of the maxilla is high (more than half of the anteroposterior length), even though its dorsal portion is incomplete (Fig. 2). The maxilla contacts the prefrontal dorsally on the left side, and the lacrimals, partially preserved on both sides, posterodorsally. The lacrimal forms the anterior wall of the orbit, with a small opening for the lacrimal duct. Medially, this bone has a long anterior extension as a thin lamina, which does not reach the antrum Highmori. The lacrimal extends posteroventrally as a long flange and meets the jugal below the orbit. The anterior extension of the jugal is posterior to the anterior margin of the orbit (Fig. 2B).

On the medial side of the maxilla, the canine boss is quite robust as in lycosuchids (van den Heever 1994: fig.5) but in contrast to Moschowhaitsia (Ivakhnenko 2011: fig.18a). Anterior to the 
129 canine boss, there is a small triangular fossa located posterior to the premaxilla, which is 130 separated by a small horizontal crest from the fossa of the lower canine. This fossa, which is 131 incompletely preserved in the specimen, is called the anterior maxillary fossa (van den Heever 132 1994) or antrum Highmori (Ivakhnenko 2011) (Table 1; Fig. 4). Ivakhnenko (2011, fig.18a) 133 identified the medial side of the antrum as partial formed by the premaxilla in Moschowhaitsia, 134 whereas the whole wall is identified as the septomaxilla in Glanosuchus (Hillenius 1994). Above, 135 the fossa is partially capped by the medially directed maxillary flange. Posterior to the canine 136 boss, there is a larger trapezoidal fossa, which opens dorsally (Fig. 4). It is commonly known as the anterior maxillary sinus (Sigurdsen 2006), and is called the sinus Highmori here following Ivakhnenko (2011). The high anterior wall of the sinus Highmori is mainly formed by the canine

boss, the medial wall by the palatine, the posterior ridge by the palatine and lacrimal, and the lateral wall by the maxilla and lacrimal. A triangular fossa, the palatine sinus, is located posteriorly to the nearly horizontal lacrimo-palatine ridge, and below the orbit. A fenestra penetrates the lacrimo-palatine ridge, so connecting the sinus Highmori and the palatine sinus. The palatine sinus is formed laterally by the lacrimal and palatine, ventrally by the palatine, and dorsally partially covered by the lamina of lacrimal. This fossa is divided by an anteroposteriorly directed low ridge, its medial portion being deeper than the lateral part. Posteromedially, the ectopterygoid forms a low crest, separating the palatine sinus from the suborbital vacuity (Fig. 4). In lateral view, most of the ventral margin of the maxilla is slightly concave anteriorly, in front of the level of the canine alveolus and remarkably convex posteriorly (Fig. 2A). In palatal view, the maxilla is constricted behind the canine. The maxilla houses the alveoli for one precanine, one functional canine, one replacing canine and eight postcanines (Figs. 3B, 5). The 
151 alveolar buccal margin is slightly laterally concave in ventral view. The buccal margins are

152 placed more ventrally than the lingual margins of the postcanine alveoli. No diastema is presents

153 behind the canine. The posterior accessory canine alveolus is much smaller than the anterior one.

154 The only preserved teeth are the third postcanines on both sides, but they are broken at their

155 bases. These teeth are circular to slightly ellipsoid in palatal view. The maxilla has a broad

156 exposure medial to the canine alveoli, approaching the wide vomer.

157 The choana is confluent with the fossa for the lower canine, and it extends anteriorly to the

158 level of fourth incisor and posteriorly to the level of the third postcanine. The choana is bordered

159 laterally by the maxilla and palatine, anteriorly by the premaxilla, medially by the vomer, and

160 posteriorly by the vomer and palatine (Fig. 3).

161 The vomer is wide anteriorly in order to abut the vomerine process of the premaxilla, but is

162 narrow on its posterior end where it contacts with the pterygoid (Fig. 3). It has a long lateral

163 suture with the palatine. The vomer is unpaired with the anterior portion having a ventrally

164 convex surface. A ventromedian crest is present on the central and posterior portion. The vomer is

165 narrowest on its middle part where it is slightly wider than the ventromedian crest, but reaches its

166 greatest width immediately behind the choana. The general structure of the vomer resembles that

167 of Promoschorhynchus (Mendrez 1974: fig. 2), but the central portion of the bone is much more

168 robust in the African taxon. On the dorsal side, the anterior part of the vomer has a high midline

169 ridge with a lower lateral one on either side (Fig. 3A). The vomeronasal organ lies in the trough

170 formed by these ridges (Hillenius 2000). The central ridge extends on the whole length of the

171 choana and it is enclosed by the vomerine lateral expansions behind the choana.

172 In ventral view, the palatine can be divided into a nearly flat lateral portion and a concave 
173 medial portion. A sharp crista choanalis is formed where these two portions meet. The crista starts

174 on the maxilla from the anterior level of the canine alveolus and continues posteriorly to the

175 center of the anterior margin of the suborbital vacuity (Fig. 3). On the lateral portion, the palatine

176 bifurcates as two anterior processes located in front of the maxillo-palatine foramen, a narrow

177 medial and a wide lateral one. This pattern is similar to that of Annatherapsidus petri

178 (Ivakhnenko, 2011: fig. 23A). The maxillo-palatine foramen lies at the level of the anterior

179 margin of the second postcanine, and should connect to the sinus Highmori by a groove within

180 maxilla (Sigurdsen 2006). The anterior margin of the palatine reaches the posterior border of the

181 additional canine alveolus. Laterally, the suture between the maxilla and palatine extends almost

182 parallel with the lateral margin of the skull on the medial side of the postcanine row (Fig. 3B).

183 Posteriorly, the palatine contacts the ectopterygoid and forms the anterior border of the suborbital

184 vacuity. Posteromedially, the palatine contacts the anterior process of the pterygoid.

185 Only the anterior process and part of the transverse process of the pterygoid is preserved. A

ventromedian ridge is continuous with that of the vomer. The pterygoid ridge becomes higher

posteriorly and expands laterally to forms a tuber between the posterior margins of the suborbital

vacuities (Fig. 3B). Lateral to this ridge, two parasagittal ridges develop on both sides. There are

no palatal teeth on the pterygoid. The suborbital vacuity is relatively small, subtriangular and

about as long as it is wide.

A relatively small ectopterygoid overlies the anterolateral portion of the transverse process

and is in contact with the pterygoid on its medial side, the palatine anteriorly, and the maxilla

laterally. There is a palatal ridge lying laterally to the posterior portion of the crista choanalis

(Fig. 3B). In the posterior portion of the palate there is a suborbital foramen located laterally to 
195 the suborbital vacuity, limited medially by the ectopterygoid and laterally by the maxilla. The

196 foramen opens in the posterior portion of the palatine sinus.

197 DISCUSSION

198 Therocephalia is well represented in the Permo-Triassic of Pangea (Huttenlocker \& Sidor 199 2016; Kemp 2005). The oldest records are from the middle Permian of the Karoo Basin, South 200 Africa (Abdala et al. 2008, 2014) and it is during the late Permian of the South African Karoo 201 Basin that they become amazingly diverse (Huttenlocker 2014). As a result of increased field 202 work in East Africa in recent years, the record of African therocephalians outside of the Karoo 203 Basin has improved (Huttenlocker \& Sidor 2016; Huttenlocker et al. 2015). In Laurasia, late 204 Permian therocephalians are known from Russia (Ivakhnenko 2011), where they have a good 205 record, although it is comparatively poor in relation to South Africa. Although middle and late 206 Permian deposits in China have revealed a diverse, species-rich vertebrate fauna (Li et al. 2008), 207 the therocephalian records have proven elusive. Thus, Liu and Abdala (2017) only recently 208 described a therocephalian from the Permo-Triassic transition zone, and Shiguaignathus wangi is 209 only the second Chinese Permian therocephalian.

210 The new taxon is diagnosed as a therocephalian by the following features: confluence of the 211 palatal fenestra with the internal naris to accommodate the lower canine, anterior expansion of 212 the portion of the vomer separating the choanae which is widest at its contact with the premaxilla, 213 presence of suborbital vacuities bounded by the palatine, pterygoid and ectopterygoid and 214 presence of a ventromedian crest anterior to the interpterygoid vacuity. $S$. wangi can be further referred to eutherocephalians due to the premaxillary rostral process overhanging incisors and the 
presence of a fused vomer.

Shiguaignathus wangi presents eight postcanines, the maximum for any akidnognathid (Fig.

5). These teeth are seven in Akidnognathus (Haughton 1918; Brink 1961) and less than seven in other akidnognathids. The snout of $S$. wangi shows a nearly straight and parasagittally directed crista choanalis which is directed towards the middle of the suborbital vacuity and ends anterior to the vacuity, the posterior margin of the choana extends till the level of the third postcanine

(Figs. 3, 6), and the anterior margin of the palatine extends far anteriorly to the maxilla-palatine

foramen as two processes. In some therocephalians, such as Moschorhinus kitchingi and

Promoschorhynchus platyrhinus, the major part of the crista choanalis is directed to the center of

the anterior margin of the suborbital vacuity (Durand 1991; Mendrez 1974) (Fig. 6). In these two

taxa, however, the posterior part of the crista choanalis is curved posterolaterally and directed

towards the lateral side of the suborbital vacuity. The extension of the posterior margin of the

choana in other akidnognathids is always beyond the third postcanine (Fig 6). The palatine

bifurcates as two processes extending far anteriorly in front of the maxillo-palatine foramen in

Annatherapsidus petri and adults of Theriognathus microps (Huttenlocker \& Abdala 2016;

Ivakhnenko 2011). In most eutherocephalians, the anterior extension of the palatine is only at the

level of the maxillo-palatine foramen. It extends anteriorly to the foramen laterally in

Pristerognathus polyodon and medially in Ichibengops munyamadziensis (Huttenlocker et al.

2015; Mendrez 1975). The maxillo-palatine foramen is located approximately at the level of the

first postcanine, slightly anterior to the posterior margin of the choana. The foramen is also close

to the posterior margin of the choana in Theriognathus, Ichibengops, Lycideops, Bauria and 
enlarged and well exposed outside the external naris, broadly overlapping the premaxilla

to the anterior margin of the orbit; and the presence of five upper incisors and functional

244 view.

\section{Phylogenetic analysis}

246 The new species was coded following Huttenlocker and Sidor's (2016) data matrix with 247 redefinition of some characters and revision of two codings (Appendices I, II) and analyzed with TNT 1.5 (Goloboff \& Catalano 2016). Three outgroups, Anomodontia, Biarmosuchus and Titanophoneus, were discarded from the final data matrix because Gorgonopsia is generally accepted as the sister group of Therocephalia plus Cynodontia (Rubidge \& Sidor 2001) and exploration of the data by phylogenetic analyses showed that there was no change in the placement of the groups of interest for this study. The routine followed for the search of most parsimonious trees (mpt) consisted of 10 random addition sequences and TBR, saving 10 trees per replications, and a second search using the trees from RAM as starting point and implementing TBR on those trees. The search resulted in $3700 \mathrm{mpt}$ of 368 steps in which major groups of Therocephalia, excepting Scylacosauridae, are monophyletic in the strict consensus

257 (Figure 7 left). S. wangi is placed either within Akidnognathidae or as the sister taxon of other 258 akidnognathids. The majority rule consensus tree (Figure 7 right) is nearly identical to the strict 
260 Bauroidea is most similar to their Bayesian consensus, represented in their figure 5a, by the

261 recovery of a monophyletic Lycideopidae. Bremer support of 1 and low values of bootstrapping

262 characterize most of the major lineages of therocephalians, being Bauridae the only exception

263 with Bremer support of 2 and resampling values above 50.

264 There are three characters supporting the sister group relationship of Akidnognathidae and

265 Chthonosauridae: vomer completely fused (character 43), posterior apophysis of epipterygoid

266 contacting the prootic (character 57), and the absence of diastema behind dominant caniniform

267 (character 127), but these characters are only known in one taxon of the Chthonosauridae. Two of

268 these characters (43 and 127) supported the inclusion of $S$. wangi within this clade in some of the

269 mpt. The synapomorphy of Akidnognathidae is the presence of vomer greatly expanded

anteriorly with the anterior width around half of the vomer length between choanae (character

$27140)$.

The majority consensus tree (Fig. 7 right) shows the basal placement of the Chinese $S$. wangi and the Russian $A$. petri, suggesting a possible origin of Akidnognathidae in Laurasia. This is the only major group of Therocephalia in which basal representatives are not from South Africa.

Other than $S$. wangi whose age is unsure right now, the oldest akidnognathids are known from the

277 Euchambersia (Huttenlocker et al. 2011). The youngest history of the group is then developed only in South Africa. Akidnognathids is the last lineage of Therocephalia to appear in the fossil record as representatives of the Baurioidea and Whaitsioidea are known from levels of the 
282 survivor is Olivierosuchus, a taxon which is only modestly represented in the Lystrosaurus AZ.

\section{CONCLUSION}

The discovery of $S$. wangi, the first therocephalian from the Naobaogou Formation, increases the diversity of this fauna, and reinforces the presence of akidnognathid therocephalians in

Laurasia. The phylogenetic analysis places the Laurasian species as basal members of this group of therocephalians, and suggests the putative origin of akidnognathid in Laurasia, the only case for a major group of therocephalians.

Institutional abbreviations

BMNH Natural History Museum, London, UK

BP Evolutionary Studies Institute, University of the Witwatersrand, Johannesburg, South

Africa

IVPP Institute of Vertebrate Paleontology and Paleoanthropology, Chinese Academy of

Sciences, Beijing, China

NMQR National Museum, Bloemfontein, South Africa

PIN Paleontological Institute, Russian Academy of Sciencies, Moscow, Russian

RC Rubidge collection, Wellwood, Graaff-Reinet, South Africa

SAM Iziko Museums-South African Museum, Cape Town, South Africa

USNM National Museum of Natural History, Washington D.C., USA 
301 For its hard work, we thank the field team that went to Daqingshan in 2009 (Wang Yu, Jia Zhen302 Yan, and Chang Shao-Ning), and especially Wang Yu who collected the specimen, Fu Hua-Lin 303 prepared it, Xu Yong made the drawing. Reviews by Adam Huttenlocker and Christian 304 Kammerer and revision of the English by Cynthia Kemp are especially appreciated.

\section{REFERENCES}

Abdala F, Kammerer CF, Day MO, Jirah S, Rubidge BS. 2014. Adult morphology of the therocephalian Simorhinella baini from the middle Permian of South Africa and the taxonomy, paleobiogeography, and temporal distribution of the Lycosuchidae. Journal of Paleontology 88:1139-1153 Doi 10.1666/13-186.

Abdala F, Rubidge BS, Van den Heever JA. 2008. The oldest therocephalians (Therapsida,Eutheriodontia) and the early diversification of Therapsida. Palaeontology 51:1011-1024.

Brink AS. 1961. On some small therocephalians. Palaeontologia Africana 7:155-182.

Brink AS. 1961. On some small therocephalians. Palaeontologia Africana 7:155-182.

Broom R. 1903. On the classification of the theriodonts and their allies. Report of the South African Association for the Advancement of Science 1:286-294.

Broom R. 1905. On the use of the term Anomodontia. Records of the Albany Museum 1:266-269.

Durand JF. 1991. A revised description of the skull of Moschorhinus (Therapsida, Therocephalia). Annals of the South African Museum 99:381-413.

Goloboff PA, Catalano S. 2016. TNT, version 1.5, with a full implementation of phylogenetic morphometrics. Cladistics Doi 10.1111/cla. 12160. 
322

323

324

325

326

327

Haughton SH. 1918. Investigations in South African Reptiles and Amphibians: 11. Some New Carnivorous Therapsida, with Notes upon the Brain_case in Certain Species. Annals of the South African Museum 12:175-216.

Hillenius WJ. 1994. Turbinates in Therapsids: evidence for late Permian origins of Mammalian endothermy. Evolution 48:207-229 Doi 10.2307/2410089.

Hillenius WJ. 2000. Septomaxilla of nonmammalian synapsids: Soft-tissue correlates and a new functional interpretation. Journal of Morphology 245:29-50.

Hopson JA, Barghusen HR. 1986. An analysis of therapsid relationships. In: Hotton N, MacLean PD, Roth JJ, Roth EC, eds. The ecology and biology of mammal-like reptiles. Washington: Smithsonian Institution Press, 83-106.

Huttenlocker AK. 2014. Body size reductions in nonmammalian eutheriodont therapsids (Synapsida) during the end-Permian mass extinction. PLoS ONE 9:e87553 Doi 10.1371/journal.pone.0087553.

Huttenlocker AK, Abdala F. 2016. Revision of the first therocephalian, Theriognathus Owen (Therapsida: Whaitsiidae), and implications for cranial ontogeny and allometry in nonmammaliaform eutheriodonts. Journal of Paleontology 89:645-664 Doi 10.1017/jpa.2015.32.

Huttenlocker AK, Sidor CA. 2012. Taxonomic revision of Therocephalians (Therapsida: Theriodontia) from the Lower Triassic of Antarctica. American Museum Novitates:1-19 Doi 10.1206/3738.2.

Huttenlocker AK, Sidor CA. 2016. The first karenitid (Therapsida, Therocephalia) from the upper Permian of Gondwana and the biogeography of Permo-Triassic therocephalians. 
Journal of Vertebrate Paleontology 36:e1111897 Doi 10.1080/02724634.2016.1111897.

Huttenlocker AK, Sidor CA, Angielczyk KD. 2015. A new eutherocephalian (Therapsida, Therocephalia) from the upper Permian Madumabisa Mudstone Formation (Luangwa Basin) of Zambia. Journal of Vertebrate Paleontology 35:e969400 Doi 10.1080/02724634.2015.969400.

Ivakhnenko MF. 2011. Permian and Triassic Therocephals (Eutherapsida) of Eastern Europe. Paleontological Journal 45:981-1144 Doi 10.1134/s0031030111090012.

Kemp TS. 2005. The origin and evolution of mammals. Oxford: Oxford University Press.

Li J, Wu X, Zhang F. 2008. The Chinese Fossil Reptiles and Their kin (second edition). Beijing: Science Press, 473.

Li J-L, Cheng Z-W. 1997. A captorhinid from the Upper Permian of Nei Mongol, China. In: Tong Y-S, Zhang Y-Y, Wu W-Y, Li J-L, and Shi L-Q, eds. Evidence for Evolution--Essays in Hornor of Prof Chungchien Young on the Hundredth Anniversary of His Birth. Beijing: China Ocean Press, 119-124.

Liu J, Abdala F. 2017. Therocephalian (Therapsida) and chroniosuchian (Reptiliomorpha) from the Permo-Triassic transitional Guodikeng Formation of the Dalongkou Section, Jimusar, Xinjiang, China. Vertebrata Palasiatica 55:24-40.

Liu J, Li L. 2013. Large tetrapod burrows from the Permian Naobaogou Formation of the Daqingshan area, Nei Mongol, China. Acta Geologica Sinica (English Edition) 87:15011507.

Mendrez CH. 1974. A new specimen of Promoschorhynchus platyrhinus Brink 1954 (Moschorhinidae) from the Daptocephalus-Zone (Upper Permian) of South Africa. 
Mendrez CH. 1975. Principales variations du palais chez les thérocéphales Sud-Africains (Pristerosauria et Scaloposauria) au cours du Permien Supérieur et du Trias Inférieur. Colloque International CNRS 218:379-408.

Nopsca FV. 1928. The genera of reptiles. Palaeobiologica 1:163-188.

Reisz RR, Liu J, Li J, Müller J. 2011. A new captorhinid reptile, Gansurhinus qingtoushanensis, gen. et sp. nov., from the Permian of China. Naturwissenschaften 98:435-441.

Rubidge BS, Sidor CA. 2001. Evolutionary patterns among Permo-Triassic therapsids. Annual Review of Ecology and Systematics 32:449-480.

Sigurdsen T. 2006. New features of the snout and orbit of a therocephalian therapsid from South Africa. Acta Palaeontologica Polonica 51:63-75.

Sun A-L. 1991. A review of Chinese therocephalian reptiles. Vertebrata Palasiatica 29:85-94.

van den Heever JA. 1994. The cranial anatomy of the early Therocephalia (Amniota: Therapsida). Annale Universiteit van Stellenbosch 1994:1-59.

Young C-C. 1952. On a new therocephalian from Sinkiang, China. Acta Scientia Sinica 2:152165.

Zhu Y. 1989. The discovery of dicynodonts in Daqingshan Montain, Nei Mongol (Inner Mongolia). Vertebrata Palasiatica 27:9-27. 
Table $\mathbf{1}$ (on next page)

Different names for the fossae on medial side of the skull of therocephalians 
1 TABLE 1. Different names for the fossae on medial side of the skull of therocephalians

\begin{tabular}{llll}
\hline Brink (1960) & maxillary antrum & \\
\hline van den Heever & anterior maxillary & posterior maxillary & posterior maxillary \\
$(1994)$ & fossa & fossa & fossa \\
\hline Sigurdsen (2006) & anterior maxillary & posterior maxillary \\
\hline Tatarinov (1999) & sinus & sinus \\
& & the postcanine part & the palatine part of \\
& & of the maxillary & the maxillary \\
\hline Ivakhnenko (2011) & antrum Highmori & sinus Highmori & palatine sinus \\
\hline
\end{tabular}

2

3 
Figure 1 (on next page)

(A), Geographical location of the Daqing Mountains fossil localities; (B), simplified geological map of the studied area showing distribution of the Naobaogou Formation and some fossil localities.

Abbreviations: Ar, Archean; C-O, Cambrian-Ordovician; C-P, Carboniferous-Permian; L, Laowopu Formation, N1-3, three members of Naobaogou Formation. 
Figure 2

Holotype of Shiguaignathus wangi (IVPP V 23297) from the Naobaogou Formation of China.

$A$, photograph and $B$, line drawing in left lateral view; $C$, photograph and $D$, line drawing in right lateral view. Abbreviations: J, jugal; L, lacrimal; M, maxilla; PF, prefrontal; PM,

premaxilla; SM, septomaxillary; smf, septomaxillary foramen. Photo credit: Jun Liu. Drawing credit: Jun Liu and Yong $\mathrm{Xu}$.
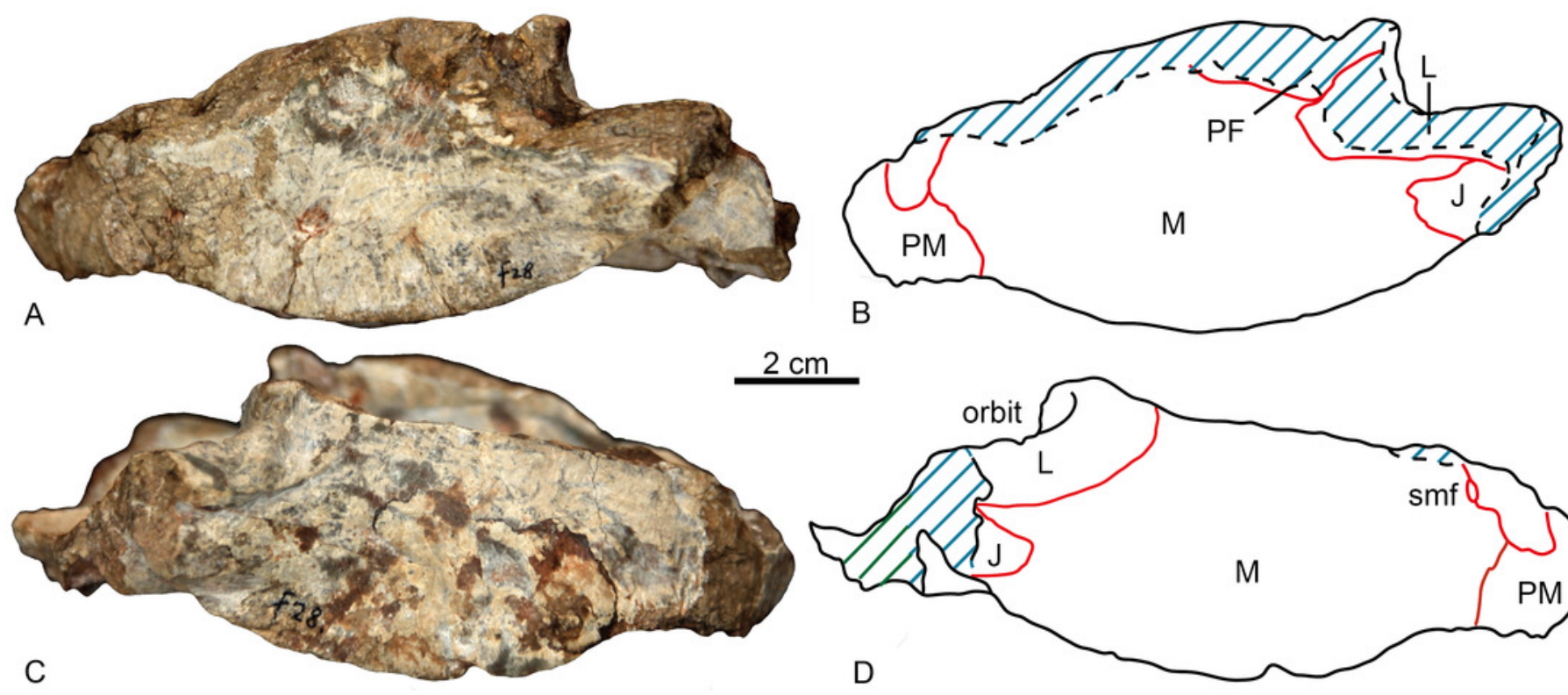

$2 \mathrm{~cm}$

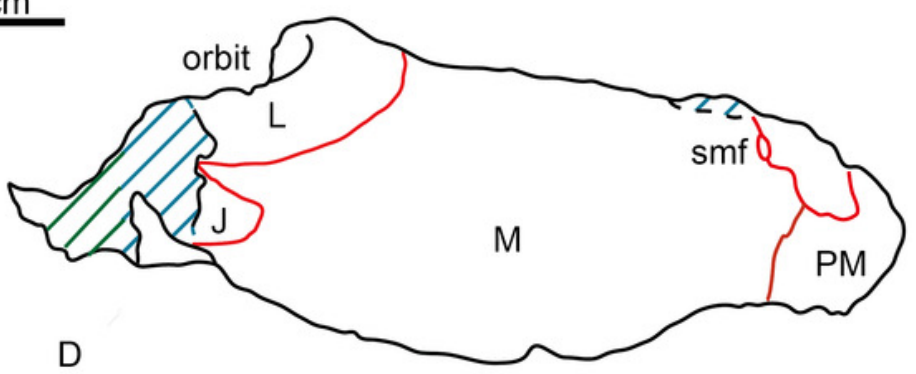




\section{Figure 3}

Holotype of Shiguaignathus wangi (IVPP V 23297) from the Naobaogou Formation of China.

$A$, photograph and $B$, line drawing in dorsal view; $C$, photograph and $D$, line drawing in ventral view. Abbreviations: ch, choana; EC, ectopterygoid; J, jugal; lo, lacrimal opening; M, maxilla; mpf, maxilla-palatine foramen; pcmt, precanine maxillary tooth; PL, palatine; PM, premaxilla; pmf, premaxillary foramen; PT, pterygoid; SM, septomaxillary; sof, suborbital foramen; V, vomer. Photo credit: Jun Liu. Drawing credit: Jun Liu and Yong Xu. 

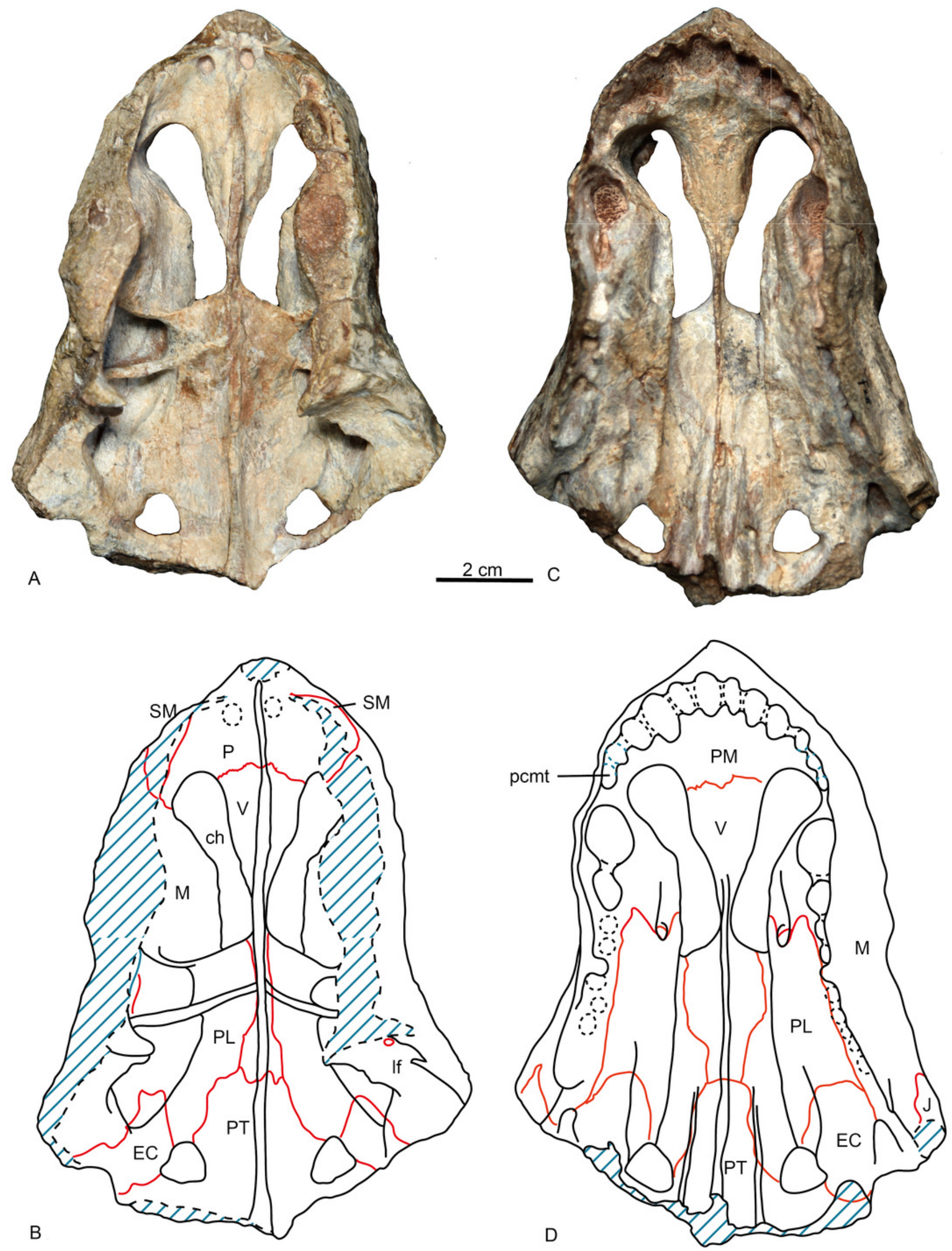


\section{Figure 4}

Holotype of Shiguaignathus wangi (IVPP V 23297) from the Naobaogou Formation of China.

A, photograph and $B$, line drawing in dorsomedial view. Abbreviations: aH, antrum Highmori; cb, canine boss; EC, ectopterygoid; L, lacrimal; ler, lacrio-ectopterygoid ridge; Ipr, lacrimopalatine ridge; M, maxilla; PM, premaxilla; $\mathrm{sH}$, sinus Highmori; sov, suborbital vacuity; sp, palatine sinus; V, vomer. Photo credit: Jun Liu. Drawing credit: Jun Liu and Yong Xu.
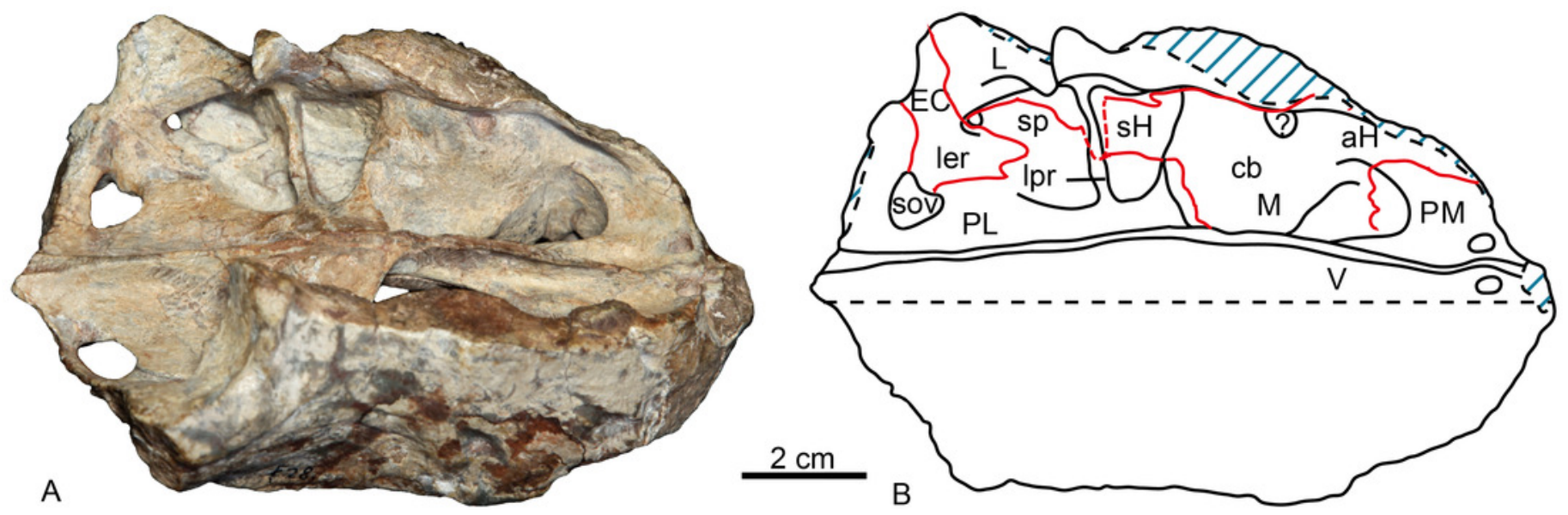


\section{Figure 5}

Holotype of Shiguaignathus wangi (IVPP V 23297) from the Naobaogou Formation of China.

A, right, B, left, maxillary toothrow in palatal view. Abbreviations: fc, functional canine; rc, replacing canine; 1-8, postcanine 1-8. Photo credit: Jun Liu. 

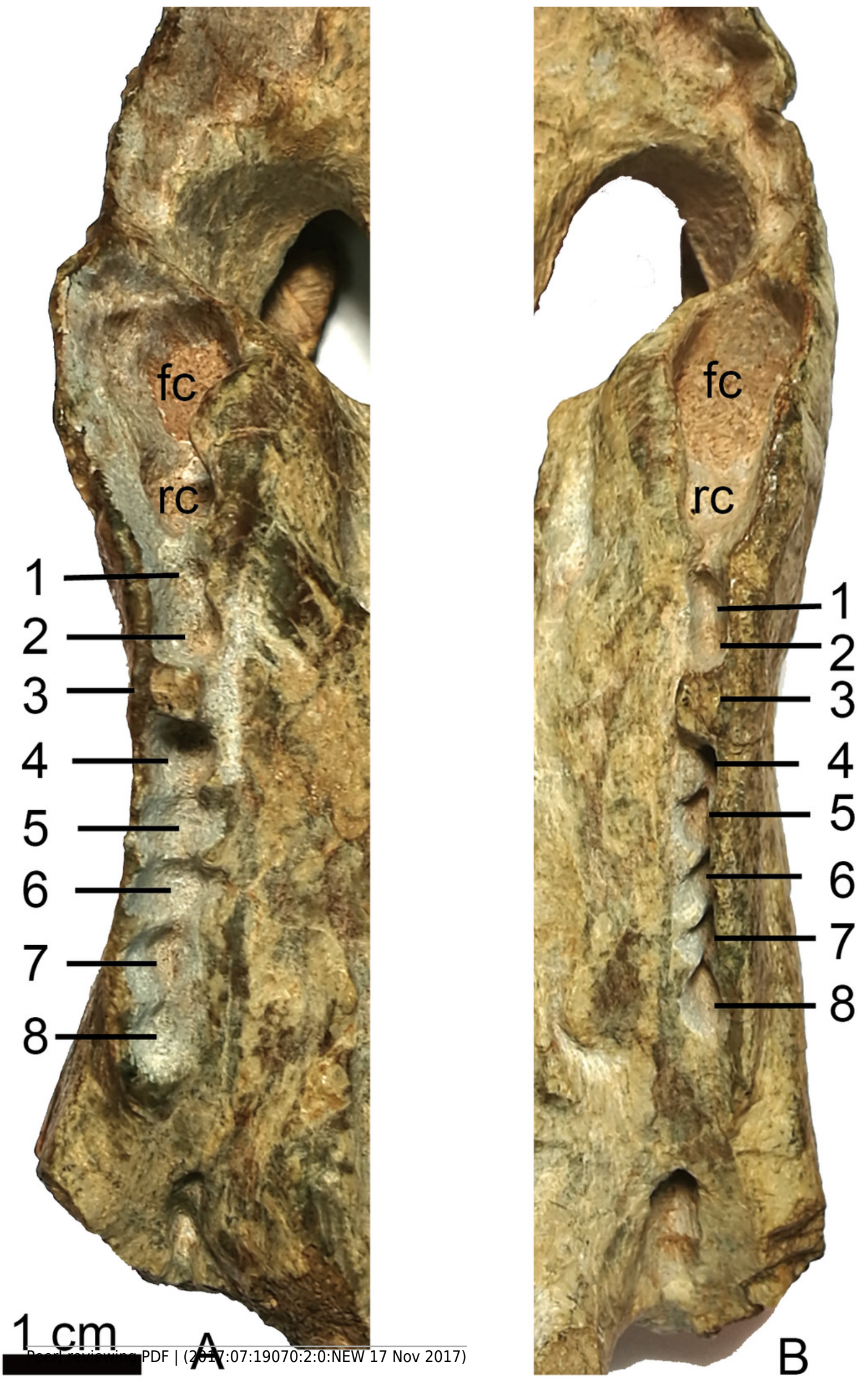


\section{Figure 6}

Comparison of akidnognathid palates.

A, Promoschorhynchus (RC 116); B, Moschorhinus (BMNH R5698); C, Annatherapsidus (PIN 2005/1992); D, Olivierosuchus (NMQR 3605); E, Shiguaignathus (IVPP V 23297); F, Akidognathus (SAM-PK-4021). Photo credit: Fernando Abdala and Jun Liu.

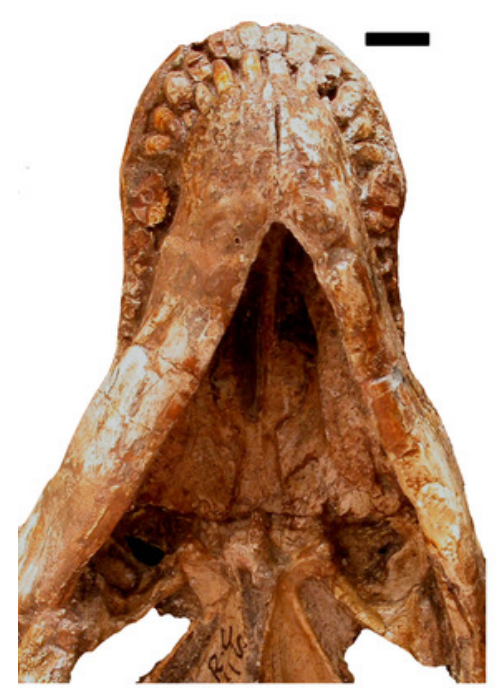

A

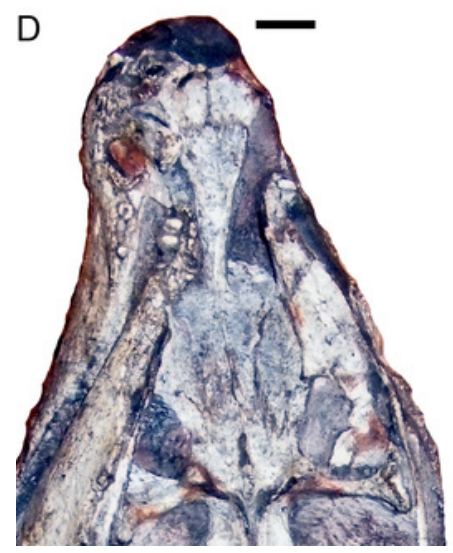

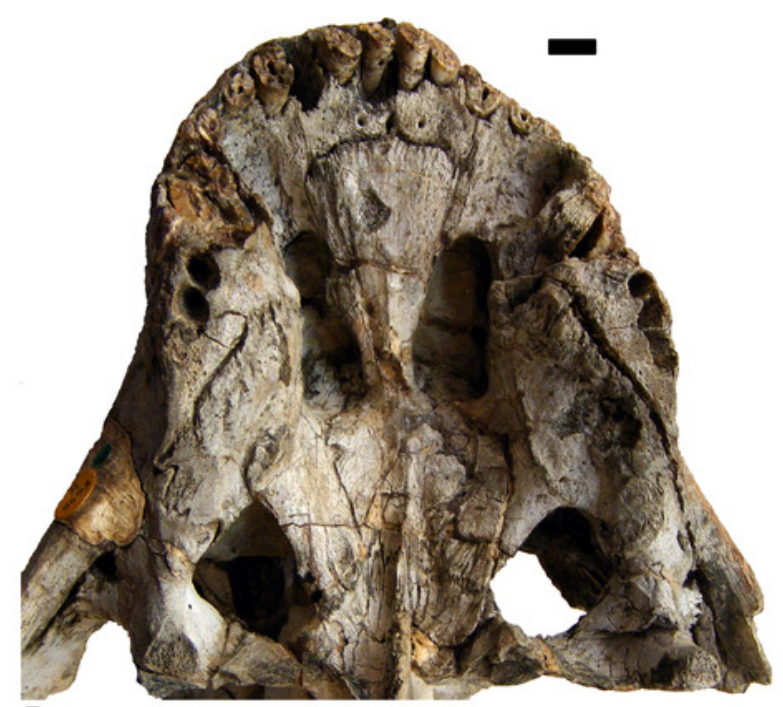

B

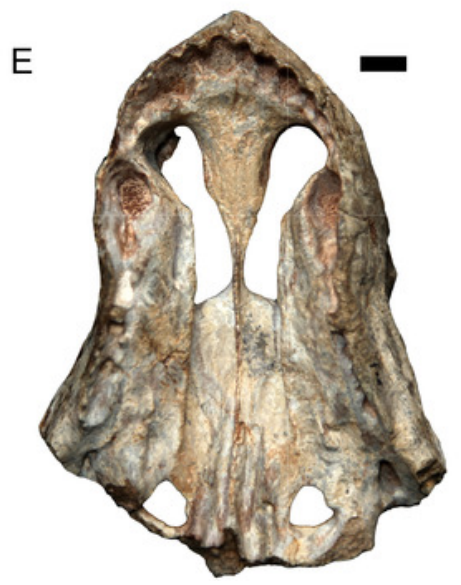

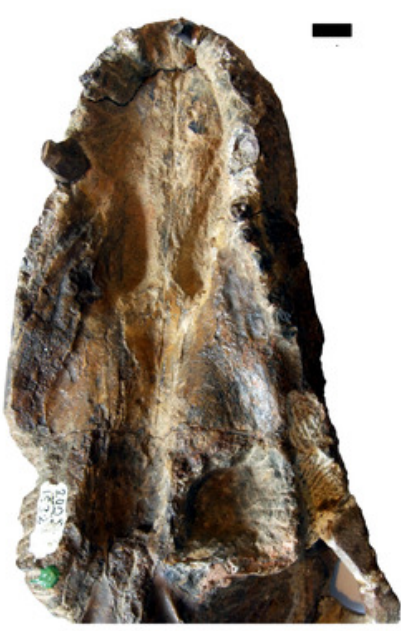

C

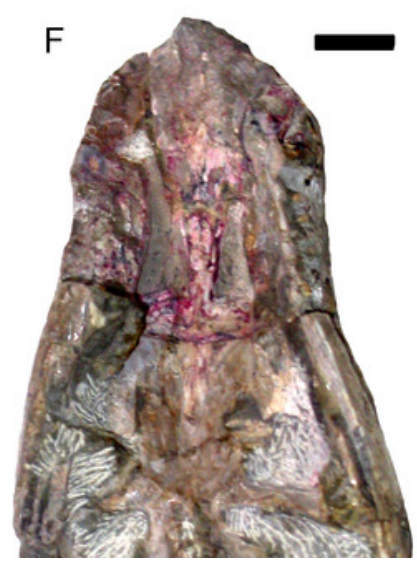


Figure 7 (on next page)

Strict (left) and majority (right) consensus trees of therocephalians.

The numbers on the right side indicate the frequency of clades in the fundamental trees. 
Lycosuchus

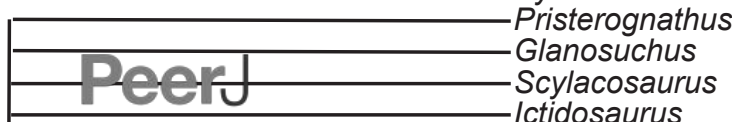

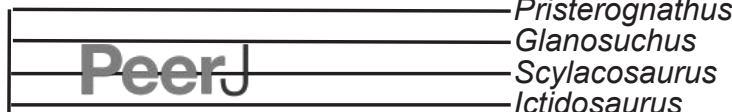

Ictidosaurus

Alopecodon

Pardosuchus

Scylacosuchus

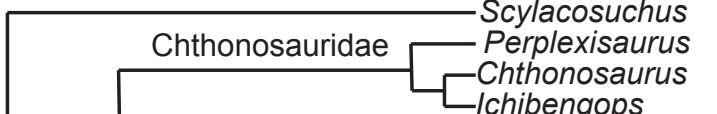

Chibengops

Shiguaignathus

Annatherapsidus

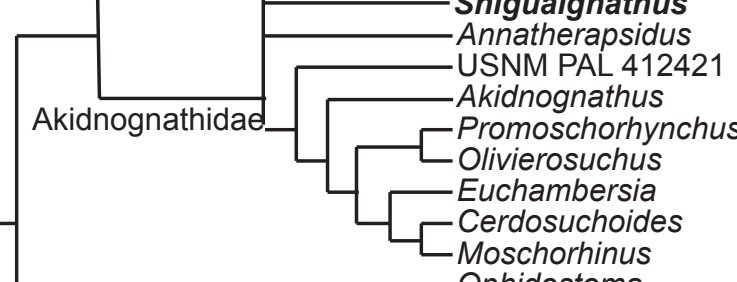
Ophidostoma
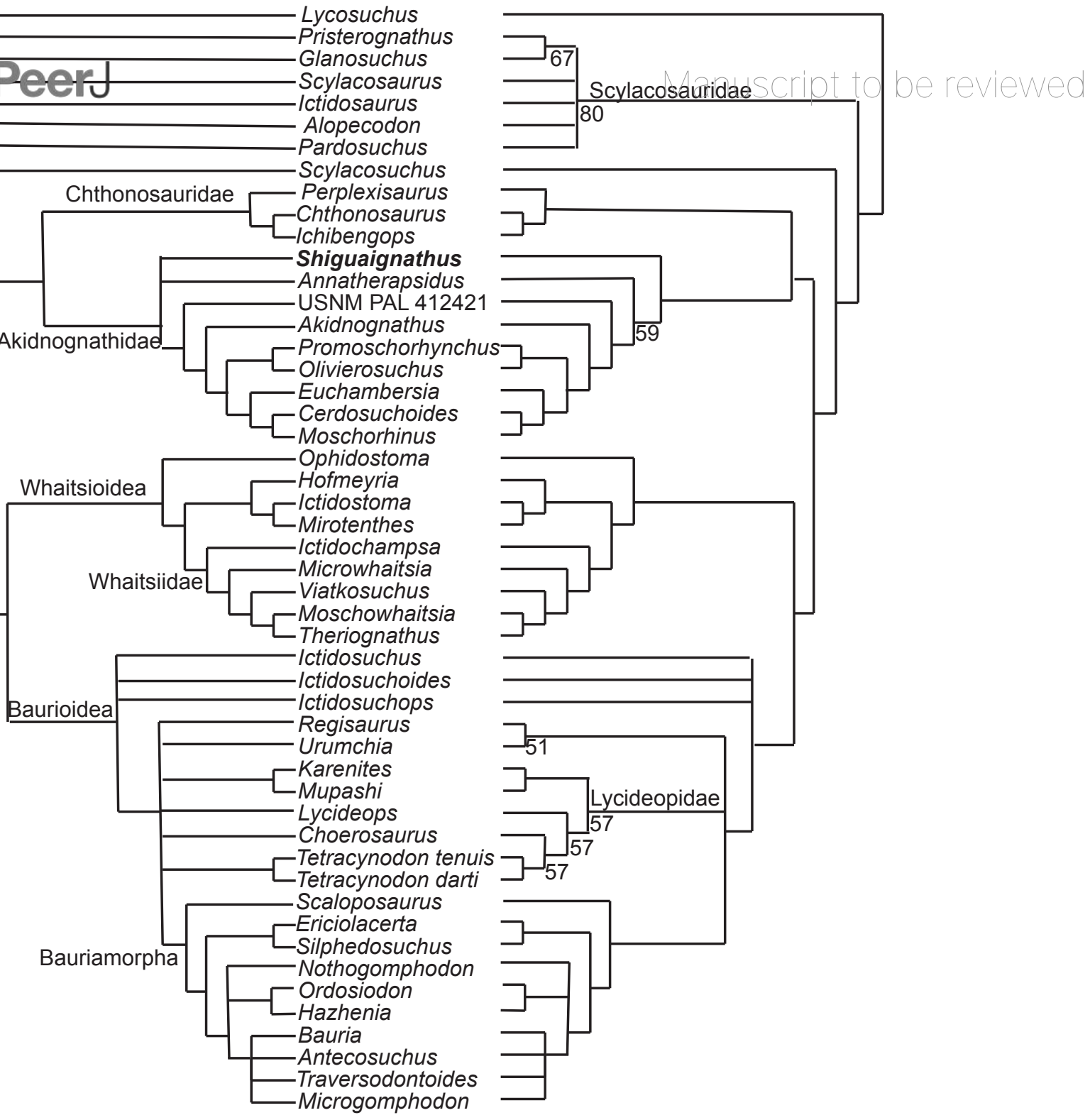